\title{
The influence of the intergenerational relationship on the academic performance of young and old college students
}

\begin{abstract}
Several studies have focused on older students. However, few studies have tested the influence of intergenerational relationships on academic performance by older students and whether there is a difference between them and younger students. This study used a qualitative and longitudinal approach to investigate the influence of the intergenerational relationship on the academic performance of young and old college students. The sample consisted of 20 students ( 10 old and 10 young people), 3 professors, and 2 employees of undergraduate courses in public and private institutions in the metropolitan region of Rio de Janeiro. We conducted semi-structured interviews with an interviewing script and an open question about the academic performance of college students using content analysis. Both the level of intergenerational relationships and academic performance were compared over 2 years using the coefficients of income. The research confirmed the hypothesis that intergenerational relationships influenced the academic performance of both older and younger students. For older people, improvement in academic performance was consistent, while for young people performance oscillated.
\end{abstract}

Keywords: intergenerational relationship, academic performance, aging, university
Volume 2 Issue 6 - 2017

\author{
Soniárlei Vieira Leite, Lucia Helena de Freitas \\ Pinho França \\ The Graduate Studies in Psychology, Universidade Salgado de \\ Oliveira, Brazil
}

Correspondence: Soniarlei Vieira Leite, The Graduate Studies in Psychology, Universidade Salgado de Oliveira, Tel 5521 999883895, Email soniarlei.vieira@gmail.com

Received: November 29, 2017 | Published: December 13, 2017

\section{Introduction}

The literature on intergroup relationships ${ }^{1}$ offers two important approaches that can be used to reduce ageism or discrimination against aging and old people: the contact hypothesis and attitudes ${ }^{2,3}$ and the multicultural perspective. ${ }^{4}$ In fact, researchers have highlighted that quality contact with persons not belonging to the same group is the factor that most influences reduction in discrimination. ${ }^{5,6}$ However, literature about multicultural factors, as a rule, generally discusses racism or sexism, and the multiage perspective is considered secondarily. ${ }^{5}$ Beyond the gains of intergenerational relationships that may reduce or eradicate age discrimination (both from young people towards old people and from old people towards young people), there is a similar scarcity of studies to validate how intergroup contact (i.e., intergenerational) and promotion of age diversity can increase academic performance among young and old people.

Institutional, school and community programs that emphasize intergenerational contact include positive measures to emphasize the values of and reinforce the self-esteem of old people. ${ }^{7}$ An effort to approximate intergenerational interactions using programs or previously planned activities is a valuable resource because old people have accumulated an endless wealth of experience and knowledge, yet they also have a lot to learn from young people; the reverse is also true. ${ }^{8}$

Education in gerontology the interdisciplinary area of human knowledge dedicated to the study of old people and policies that affect them ${ }^{9}$ is a representative of the study of the science of aging. The education dimension is fundamental in the aging stage of life. Development of old students, therefore, is seen in different forms both within the college environment and outside of it. Of note are projects that aim to achieve excellent satisfaction and quality of life among old individuals, in addition to, as a consequence, the satisfaction of college students as a whole.

Facilitating intergenerational interactions in a college environment between young and old people enables reciprocal and beneficial learning for both age groups, and this interaction may positively influence their quality of life. In the words of González-Celis et al. ${ }^{10}$ this facilitation is an efficacious way for social integration and cultural enrichment of the older population and is the locus of intergenerational learning for young individuals.

Baltes \& Baltes ${ }^{11}$ by using the selection, optimization and compensation (SOC) model, observed that individuals often use these three instruments to adapt for the natural process of aging. "Selection" leads to the development of goals to create results from making decisions on how to achieve expected results.

In the life pathway, it is natural that some skills and resources decline. As a matter of fact, it is also natural for people select what they need for this purpose; for this, they "optimize" their instruments to better use their time, effort and resources to seek the best performance possible taken as the premise for the expected results. In addition, to deal with losses and maintain positive behavior towards people's lives, the use of "compensation" is suggested. Previously established resources lead to expected results, and people might use other forms and ways (alternatives) to achieve the same results. ${ }^{11}$

One might think, based on SOC model, that old college students can use the adaptive instrument for the college environment in order to maintain a successful academic life, as affirmed by Baltes \& Dickson ${ }^{12}$ in relation to the work site. Another relevant theory about development throughout life is the socio emotional selectivity theory. ${ }^{13}$ This theory focuses on the process of selecting how behavior is adjusted and related to perception of time. As time passes, people 
become more selective; they also prefer to broaden their emotional and social experiences on the one hand and reduce, on the other hand, emotional and social risks. ${ }^{14}$ Still, according to this theory, young adults tend to perceive time as something open, and, therefore, they prioritize future goals oriented by knowledge acquisition. To them, this learning is immediate.

The educational process is not restricted to the classroom but extends to convivence and sharing. In this new paradigm, reflect about the issue is fundamental, especially because intergenerational relationships are a reality in the current academic environment. The question should be whether this convivence between young and old individuals is a predictor that favors their teaching-learning process, especially for old people, because of the imminent demographic challenge. Is it possible to affirm that intergenerational relationships only create benefits, even considering conflicting relationships? In fact, investigations must also consider how the old college students are perceived by young students and vice-versa; in addition, there is a need to understand how this contact benefits both age groups.

This study is important because intergenerational convivence represents a learning opportunity to everyone involved in social relationships, translating into a reciprocal social participation in which both old and young individuals are receptors, donors, or transmitters of knowledge. ${ }^{7}$

When the receptor is an old individual, entering or reentering an educational environment might transform his or her life; in addition, the older person is a transmitter because the individual is prompted to reflect about his or her values and own life history. ${ }^{15}$ Young people might update old people about the use of language and technology. ${ }^{16}$

\section{Method}

This longitudinal study collected data over a 2-year period. In a longitudinal design, the same sample of individuals is measured and analyzed over a specific period of time. The analysis compared data obtained at different steps of the study. A qualitative approach is justified because we did not find an adequate scale with which to analyze the association between intergenerational relationships and academic performance; few alternatives exist, and those that can be used are focused on intergenerational solidarity. The content of the interviews was analyzed. In our study the analysis included two categories (intergenerational relationship and academic performance). The study sought to confirm whether intergenerational relationships would be a predictor of academic performance.

\section{Participants}

The study included 25 participants. Of these, 20 were students (10 aged 60 years or older and 10 aged 18 to 25 years), 2 were employees and 3 were professors of undergraduate courses from private and public universities located in the city of Rio de Janeiro, Brazil. Students were randomly selected in an academic system of educational institutions and the single criterion used was age range. Professors and employees were indicated by institution directors based on their availability considering their schedule.

\section{Instrument}

We adopted a semi structured interview technique and an interview model to extract participants' perceptions about relationship between the two age groups, but we included the issue related to academic performance within the last 2 years. In addition, we used the grade point average, collected from the academic system after authorization, according to courses and entered that information in tables for analysis. Interviews occurred, especially as narratives: i.e., questions were designed as subtle interventions using the participant's voice from the first manifestation. Interviews always started with a question about how the person feels in the university setting and what the relationship with colleagues was like in order to identify reports of participants about the following issues to reveal the homogeneity and heterogeneity of undergraduate students:

\section{Interview script}

i. What is the relationship between young individuals and old individuals in the classroom like? How close do they come to each other

ii. Does their approximation interfere with the personal development of both groups? How does this interference occur?

iii. Do young individuals and old individuals behave the same or differently in the classroom? Give some examples.

iv. Does their behavior influence personal development? How does this influence occur?

v. Do you see any relationship between students' income and their development? How does this relationship occur?

vi. Do formal education and origin of students (public or private high school) influence approximation of old individuals with young individuals? How does this influence occur?

vii. Does formal education affect students' academic results? Were such results observed?

viii. Does professional experience influence the convivence of old individuals with young individuals? How does professional experience influence this convivence?

ix. Can professional experience influence the convivence of old students with young students? If so, what extent professional experience influences this convivence?

x. How does students' (young or old) performance correlate with professional experience ? If so, how can it be observed?

xi. Can group participation (young and old individuals) in activities of seizures and diversity influence development of both groups? What are activities developed by the two generations and how do they occur?

\section{Open question}

How do you evaluate the academic performance of old students compared with young students after two years of convivence with other students from your class? Does the relationship contribute or not contribute to the improvement in performance of both groups?

\section{Procedures}

The study was evaluated and approved by the Ethical and Research Committee of the University. All participants signed with the consent form. Data were collected for approximately four months. At the beginning of the interviews, we communicated to all participants that they could leave the study whenever they wanted, 
that they were participating as a volunteer, that no compensation was provided for participating, and that participants' identity was kept confidential. Authorization was requested from participants to allow the recording of interviews, as was their signature on a consent form. We informed participants that signature on the consent form would imply authorization to use information collected exclusively for the study during interviews.

\section{Data analysis}

Interviewers allowed the recording of content for posterior analysis; for this reason, a consent form was signed. Interviews were based on different day-by-day situations in the university that were reported by participants; saturation criteria were respected. ${ }^{17}$ Participants were divided into groups. The identification code EJ was given for individuals aged 18 to 25 years or younger (1 to 10). For those aged 60 years or older, the identification code use was EI or older (1 to 10). For professors and employees, the codes used were $\mathrm{P}$ (1 to 3 ) and $\mathrm{F}$ ( 1 to 2 ), respectively. Interviews were evaluated by content analysis by establishment of interviewing categorization. Content analysis corresponded to a set of techniques whose objective was to seek the meaning or meanings of a document. The set of techniques for communication analysis is fundamental, and semantic

Table I Categorization by units of sense according to narrative of participants observation is understood as a study of the sense of the text for correct application of the method..$^{18}$

Coefficients of income, after authorization of institutional coordinators, were obtained directly from the institutional academic systems at three different times during two years (from 2014 to 2016). We entered data into spreadsheets and analyzed them by using graphs with growth curves to attest evolution in academic performance.

\section{Results}

From the analysis of the content of the interviews, we categorized responses based on the number of times that a concept term or construction was used in the form conceived by Bardin ${ }^{19}$ according to related categories described in the Table 1 . Because of the longitudinal design of the study, the constructs "intergenerational relationship" and "academic performance" became the focus of this study once they were raised as possible prediction variables. After transcription, the narratives were separated by unit of sense. Unit of sense corresponded to studied attributes and showed relevance, influence and eventual relationships among them. To confirm results of perceptions of interviewers related to intergenerational influence on academic performance of young and old college students, the coefficients of income are described in Table 2.

\begin{tabular}{|c|c|c|c|c|}
\hline Partic. & Age & Sex & Unit of sense & Category \\
\hline EJ2 & 22 & $M$ & $\begin{array}{l}\text { "...I see the relationship with old guys as normal, they usually make the class flow more calmly. } \\
\text { People respect them more because they are old, I believe that it is good for everyone..." }\end{array}$ & 1 \\
\hline Ej8 & 23 & $M$ & $\begin{array}{l}\text { "...lt is good to work with old individuals. They are funny, sometimes boring, but they are good } \\
\text { people..." }\end{array}$ & 1 \\
\hline EJ9 & 19 & $\mathrm{~F}$ & $\begin{array}{l}\text { "...The first time that an old guy appeared at the bar, it was kind of weird, but the second time, } \\
\text { other old guys came, and it was fun. Today, it is common. They are funny and part of the team. It is } \\
\text { good; they are more organized and help the younger people...(laughs). }\end{array}$ & 1 \\
\hline ElI & 62 & $\mathrm{~F}$ & $\begin{array}{l}\text { "... after the } 2 \text { years that you've been here, I feel like l'm another person giving an interview. I'm } \\
\text { more confident with my convictions and I am sure that l've chosen the right pathway by returning } \\
\text { to college.You can see that it is true - just compare my grade history. No doubt that I became a } \\
\text { better person..." }\end{array}$ & 2 \\
\hline El2 & 63 & $\mathrm{~F}$ & $\begin{array}{l}\text { "...The boys and girls are very patient, they welcomed us very well in events and meetings... } \\
\text { this reflected on our development, yes, because we became a team and this interaction is now } \\
\text { general. I do not feel different because of my age. Old people are as good as young people and in } \\
\text { some disciplines, older people are even better. In philosophy, for example, we are just dynamite... } \\
\text { (laughs)..." }\end{array}$ & 1 \\
\hline EI7 & 66 & M & $\begin{array}{l}\text { "... It is a daily learning. We need patience to understand differences. In the classroom, we are a } \\
\text { team. This creates a balance because we ended up being responsible for them, as parents. This } \\
\text { environment helps us to became better persons and also to put more effort into studies..." }\end{array}$ & 1 \\
\hline ElIO & 67 & M & $\begin{array}{l}\text { "...Those guys are very good, they came from good families and they have plenty of patience with } \\
\text { us. It is not easy. The old guys are not easy to deal with (laughs)..." }\end{array}$ & 1 \\
\hline $\mathrm{PI}$ & 45 & $\mathrm{~F}$ & $\begin{array}{l}\text { "... I'm not sure about numbers, but younger students have become better as time passed. I know } \\
\text { some of them got 'As' in complicated disciplines..." }\end{array}$ & 2 \\
\hline P2 & 48 & $\mathrm{~F}$ & $\begin{array}{l}\text { "... in the beginning, there was a big concern. There is, of course, an adaptation phase, and } \\
\text { performance on tests is improving each semester. In general, they are growing..." }\end{array}$ & 2 \\
\hline F2 & 22 & $\mathrm{~F}$ & $\begin{array}{l}\text { "...I did make good old friends. They helped me a lot and they told that in the end it was me that } \\
\text { helped them... (laughs)..." }\end{array}$ & 2 \\
\hline
\end{tabular}

EJ,Young Student; El, Old Student; P, Professor; F, Employee; M, Male; F, Female; Category I, Intergeneration Relationship; Category 2, Academic Performance 
Table 2 Academic performance by coefficients of income

\begin{tabular}{|c|c|c|c|c|c|}
\hline Participants & Age & Sex & CRI & CR2 & CR3 \\
\hline EJI & 22 & $M$ & 7.2 & 7.8 & 8.1 \\
\hline EJ2 & 23 & $\mathrm{~F}$ & 6.6 & 7.1 & 6.6 \\
\hline EJ3 & 19 & $\mathrm{~F}$ & 7.8 & 8.1 & 8.8 \\
\hline EJ4 & 21 & $M$ & 9.3 & 9 & 9.3 \\
\hline EJ5 & 22 & $\mathrm{~F}$ & 5.3 & 5.8 & 7 \\
\hline EJ6 & 19 & $M$ & 6.8 & 7.2 & 6.5 \\
\hline EJ7 & 18 & $M$ & 7.8 & 7.6 & 6.6 \\
\hline EJ8 & 25 & $\mathrm{~F}$ & 5.9 & 7.6 & 6.6 \\
\hline EJ9 & 23 & $\mathrm{~F}$ & 7.6 & 8.7 & 7.8 \\
\hline EJIO & 22 & $\mathrm{~F}$ & 7.8 & 8 & 6.5 \\
\hline EII & 60 & $M$ & 5.4 & 5.6 & 6 \\
\hline EI2 & 62 & $M$ & 6.7 & 7.8 & 7.9 \\
\hline El3 & 65 & $\mathrm{~F}$ & 5.6 & 5.7 & 6.2 \\
\hline El4 & 61 & $M$ & 5.9 & 6.9 & 6.8 \\
\hline EI5 & 60 & $\mathrm{~F}$ & 7 & 7.8 & 8.2 \\
\hline El6 & 66 & $M$ & 6.8 & 6.9 & 7.3 \\
\hline EI7 & 60 & $M$ & 5.5 & 5.9 & 6.2 \\
\hline El8 & 64 & $\mathrm{~F}$ & 5 & 5.4 & 5.5 \\
\hline EI9 & 62 & $\mathrm{~F}$ & 5.8 & 6.2 & 6.5 \\
\hline EllO & 60 & $M$ & 8.1 & 8 & 8.3 \\
\hline
\end{tabular}

EJ, Young students; El, Old Students; M, Male; F, Female; CR, Coefficients of Income

In Figure 1 the evolution in each age group is evident in the curves presented. The curve for old individuals is growing and constant, whereas the curve for young individuals is also growing, but irregularly.

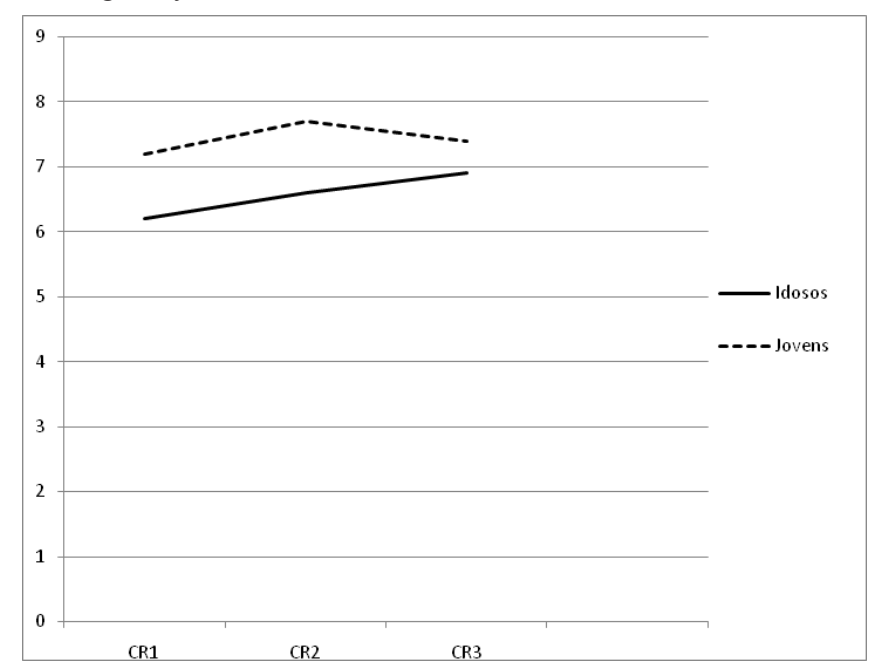

Figure I Evolution of academic performance of young and old students over two years.

\section{Discussion}

As expected, the relevance of intergenerational relationships was confirmed in the academic environment, unified by positive behaviors. Old college students affirmed the importance of contact between generations for their self-improvement, which young students did not always see as a calm relationship.

\section{Unit of sense}

i. "...It is good to work with old individuals. They are funny, sometimes boring, but they are good people..." (EJ8)

ii. "...Those guys are very good, they came from good families and they have plenty of patience with us. It is not easy. The old guys are not easy to deal with (laughs)...” (EI10).

Intergenerational relationships require some degree of tolerance between parties, but when the initial barriers are overcome, this relationship is healthy throughout time, corroborating the findings of previous studies. ${ }^{20,21}$ There was evidence of influence of old over young individuals, and vice-versa, in relation to life and profession; positive attitudes were seen from young students, and these data are confirmed in specialized literature..$^{22}$

\section{Unit of sense}

i. "... I see the relationship with old guys as normal; they usually make the class flow more calmly. People respect them more because they are old; I believe that it is good for everyone..." (EJ2),

ii. "... It is a daily learning. We need patience to understand differences. In the classroom, we are a team. This creates a balance because we ended up being responsible for them, as parents. This environment helps us to become better persons and also to put more effort into our studies..." (EI7).

A relevant aspect is the relationship between leisure time and intergenerational relationships. Studies have predicted personal development from sharing of leisure activities, pleasure and fun [23]. In our study, a number of reports confirmed the importance of sharing leisure activities, reunions, and fun as integrators of intergenerational relationship in the academic sphere, resulting in an ideal environment for the development of old and young students.

\section{Unit of sense}

i. "... The first time that an old guy appeared at the bar, it was kind of weird, but the second time, other old guys came, and it was fun. Today, it is common. They are funny and part of the team. It is good; they are more organized and help the younger people...(laughs). (EJ9)

ii. "... The boys and girls are very patient, they welcomed us very well in events and meetings...this reflected on our development, yes, because we became a team and this interaction is now general. I do not feel different because of my age. Old people are as good as young people and in some disciplines, older people are even better. In philosophy, for example, we are just dynamite...(laughs)..." (EI2).

The open question related to academic performance in the last two years, considering the time since the initial interview, confirmed the expectation related to academic performance, not only because 
of coefficients of income but also related to personal and human development.

\section{Unit of sense}

i. “... I'm not sure about numbers, but younger students have become better as time passed. I know some of them got 'As' in complicated disciplines..." (P1)

ii. "... in the beginning, there was a big concern. There is, of course, an adaptation phase, and performance in tests is improving each semester. In general, they are growing...” (P2),

iii. ... "... I did make good old friends. They helped me a lot and they told that in the end it was me that helped them... (laughs)..." (F2)

iv. " ... after the 2 years that you were here, I feel like I'm another person giving an interview. I'm more confident with my convictions and I am sure that I've chosen the right pathway by returning to college. You can see that it is true just compare my grade history. No doubt that I became a better person...” (EI1).

In graphic analysis of academic performance, based on coefficient of income over two years, we observed in both age groups an evolution of academic performance, but there is evidence of growing, as a rule, without large oscillations. Regarding young individuals, we also confirm growth in performance, but there are important oscillations showing irregularity in performance; in the end, however, performance was positive.

This result seems to confirm the disseminated impression about regularity in studies that investigated old individuals. ${ }^{24}$ This growth, although different in each age group, revealed, and corroborated the narrative analysis, a positive influence of intergenerational relationships on academic performance in both groups. Studies have shown the importance of a variety of family relationships between young and old individuals. In this sense, development of general citizenship grows, regardless of the age. ${ }^{25}$ Important studies show no significant difference in decision making between young and old adults. ${ }^{26}$ This lack of difference is more common in homogenous groups, like the one included in our study, because all college studies apparently had a similar socioeconomic standard. In making the decision to enter and reenter the university world, older individuals also have a determination to achieve better results. This is the result of maturity, which favored old students; maturity seems to measure age and well-being throughout life. ${ }^{27}$

\section{Conclusion}

Results of our study confirmed that intergenerational relationships favor the academic performance of both group of students (young and old). A number of reports corroborated the analysis of content of the semi-structured interviews we conducted. Reports were emphasized that expressed how the intergenerational relationship benefitted convivence in the college environment. ${ }^{28}$ It is important to highlight that convivence extended beyond the college walls and that the interpersonal relationships became common during leisure and fun times, times that were aggregating and important for creating common identity. These data were also observed in assessment of coefficients of income; during the period, these had ascendency, mainly a consistent trend of improvement in old students.

Still, this study showed that legal definition of timing limit for characterization of old individuals is no longer significant, because homogeneity of those entering in universities makes possible differences, which had been apparent, disappear. Intergenerational relationships, sometimes imposed by a work group, are relevant as way to provide social inclusion and for young and old individuals to overcome cultural barriers and stereotypes. ${ }^{29}$ The intergenerational relationship is important for reducing general discrimination and ageism.

Given the scarcity of studies comparing young and old individuals in an academic environment, further studies about the current relationship between intergenerational and academic performance are warranted. We also recommend the construction of a scale that can serve as an instrument for quantitative measurement, given the lack of such an instrument in our study.

\section{Acknowledgements}

None.

\section{Conflict of interest}

The authors have no conflict of interest.

\section{References}

1. Yzerbyt V, Demoulin S. Intergroup relations. In: Fiske S, Lindzey G, editors. Handbook of social psychology. Hoboken, Wiley \& Sons, USA; 2010. p. 1024-1083.

2. Allport G. The nature of prejudice. Addison-Wesley, USA; 1954.

3. Siqueira BA, França LHFP, Valentini F, et al. (no prelo) Ageismo no contexto organizacional - a percepção de trabalhadores brasileiros [Ageism in organizational context - a perception of Brazilizan workers]. Brazil.

4. Wolsko C, Park B, Judd C, et al. Framing interethnic ideology: effects of multicultural and color-blind perspectives on judgments of groups and individuals. Journal of Personality and Social Psychology. 2000;78:536-654.

5. Torres C, França LHFP, Oliveira A, et al. Diagnóstico de diversidade cultural e inclusão nas organizações [Diagnosis of cultural diversity and inclusion in organizations]. In: Mendonça H, Vetor, editors. Diversidade em organizações: teoria e prática, 2016. p. 195-228.

6. Richeson J, Nussbaum R. The impact of multiculturalism versus blindness on racial bias. Journal of Experimental Social Psychology. 2003;14:109-118.

7. França L, Silva A, Barreto M. Programas intergeracionais: quão relevanteseles podem ser para a sociedade brasileira? [Intergenerational programs: how relevant are they to Brazilian society?]. Revista Brasileira de Geriatria e Gerontologia. 2010;13(3):519-531.

8. Brouwer M, Boros S. The influence of intergroup contact and ethnocultural empathy on employees' attitudes toward diversity. Cognition, Brain, Behavior: An Interdisciplinary Journal. 2010;14:243-260.

9. Cachioni M, Neri A. Educação e gerontologia: desafios e oportunidade [Education and gerontology: challenges and oportunities]. $\mathrm{RBCEH}$ Revista Brasileira de Ciências do Envelhecimento Humano. 2004;99-115.

10. González CR, Esquivel H, Jiménez F. Impacto de un aula para personas mayores sobre la calidad de vida. Una experiencia inter-generacional. Avances de un proyecto. [Impact of classroom for old individuals about quality of life: an intergenerational experience, a project advances]. Revista Interamericana de Educación de Adultos. 2005;27(1):95-109. 
11. Baltes PB, Baltes MM. Psychological perspectives on successful aging: the model of selective optimization with compensation. In: PB Baltes,MM Baltes, editors. Successful aging: perspectives from the behavioral sciences NY: Cambridge University Press, USA; 1990;3(1):1-34.

12. Baltes PB, Dickson MW. Using life-span models in industrialorganizational psychology: The theory of selective optimization with compensation. Applied Developmental Science. 2001;5(1):51-62.

13. Carstensen LL. Selectivity theory: Social activity in life-span contexto. In: Schaie KW, editor. Annual review of gerontology and Geriatrics. Springer, USA; 1991. p. 195-217.

14. Carstensen LL, Isaacowitz DM, Charles ST. Taking time seriously: A theory of Socioemotional selectivity. The American Psychologist. 1999;54(3):165-81.

15. Freitas E, Barbosa A, Scoralick LN, et al. Tarefas de desenvolvimento e história de vida de idosos: análise da perspectiva de Havighurst [Development tasks and history of life of old individuals: analysis on Havighurst's perspective]. Psicologia: Reflexão e Crítica. 2013;26(4):809-819.

16. Verona $\mathrm{S}$, Cunha $\mathrm{C}$, Pimenta $\mathrm{G}$, et al. Percepção do idoso em relação à Internet [Perception of old individuals related with internet]. Temas em Psicologia. 2016;14(2).

17. Fontanella B, Magdaleno P. Saturação teórica em pesquisa qualitativa: contribuições psicanalíticas [Theoretical saturation in qualitative study: psicanalitic contributions]. Psicologia em Estudo. 2012;17(1):63-71.

18. Bauer M, Gaskell G. Pesquisa qualitativa com texto, imagem e som: ummanual prático [Qualitative study with text, image and song: an pratical manual]. Petrópolis: Vozes, Brazil; 2014.

19. Bardin L. L'Analyse de contenu, 2nd edn. Presses Universitaires de France, France, Paris; 2013.

20. Min J, Silverstein M, Lendon JP. Intergenerational transmission of values over the family life course. Advances in Life Course Research. $2013 ; 17: 112-120$

21. Pszemeiarower S, Pochtar N. Relações intergeracionais como contribuição para umacultura de paz [Intergenerational relations as contribution for culture of Peace]. A terceira idade Estudos sobre o envelhecimento. 2011;22:49-66.
22. Kalisch H, Coughlin D, Ballard S, et al. Old age is a part of living: student reflections on intergenerational service-learning. Gerontology \& Geriatrics Education. 2013;34(1):99-113

23. Habblethwaite S, Norris J. Expressions of generativity through family leisure: experiences of grandparents and adult children. Interdisciplinary Journal of Apllied Familiy Studies. 2011;60:121-133.

24. Oliveira MF, Machado TS. Tradução e validação da escala de resiliência para estudantes de ensino superior [Translation and validation of resilience scale for college students]. Análise Psicológica. 2011;29(4):579-591.

25. Mendes PC, Leandro CR, Lopes M. Práticas intergeracionais e interdisciplinares na educação - um exemplo prático no ensino básico [Intergenerational practices and interdisciplinar in education - a pratical example in primary education]. Revista Portuguesa de Pedagogia. 2017;51(1):63-82.

26. Schneider DDG, Parente MAMP. O desempenho dos adultos jovens e idosos na Iowa Gambling Task (IGT): um estudo sobre a tomada de decisão [Performance of young and old individuals in Iowa Gambling Task (IGT): a study on decision making]. Psicologia: Reflexão e Crítica. 2006;19(3):442-450.

27. Sheldon KM, Kasser T. Getting old, getting better? Personal strivings and psychological maturity across the life span. Developmental Psycholog. 2001;37(4):491-501

28. Warren KE. African American female secondary school educators: their teacher-student relationships and how their relationships with their student's parents, colleagues, and administrators affect the teacherstudent relationship. Doctoral thesis, ProQuest Dissertations Publish, Mississipi State University, USA; 2017.

29. Ferreira ASA. Capacitação do idoso para a melhoria de sua qualidade de vida integral: o prazer de viver, relacionando-se com o outro. Dissertação de mestrado, Repositorium, Portugal; 2014. 